\title{
Positive Regulation of Cell Death
}

National Cancer Institute

\section{Source}

National Cancer Institute. Positive Regulation of Cell Death. NCI Thesaurus. Code C40715.

Any process that increases the frequency, rate or extent of cell death. 